\title{
Penerapan Model Problem Based Learning Untuk Meningkatan Pembelajaran Matematika Bangun Ruang
}

\section{Mega Puspitasari}

Universitas Sebelas Maret

megapuspita16@gmail.com

\section{Article History}

received 30/4/2021

\begin{abstract}
This study aims to describe the application of the PBL model, improve mathematics learning, describe constraints and solutions. This research is a collaborative classroom action research. Data collection techniques using observation, interviews, documentation, and tests. The data analysis technique was carried out using three stages, namely data reduction, data presentation, and drawing conclusions. The results of this study are: steps for implementing the PBL model, namely: problem orientation, learning organization, guidance, presentation of results, analysis and evaluation, the application of the PBL model can improve learning outcomes about building space. Constraints in using the PBL model, namely: not all students follow the lesson, students have difficulty when in groups, students have not recorded conclusions, students are not confident, students are passive. The solution, namely: directing to join other friends, dividing groups before the implementation of learning, asking students to record conclusions, giving motivation, giving directions so that students are active. The conclusions of this study indicate that the application of the PBL model can improve mathematics learning about building space in fifth grade students of SDN 1 Jatisari in the 2020/2021 school year.
\end{abstract}

Keywords: Problem Based Learning, Build Space

\begin{abstract}
Abstrak
Penelitian ini bertujuan mendeskripsikan penerapan model PBL, meningkatkan pembelajaran matematika, mendeskripsikan kendala solusi. Penelitian ini merupakan PTK kolaboratif. Teknik pengumpulan data menggunakan observasi, wawancara, dokumentasi, dan tes. Teknik analisis data dilakukan menggunakan tiga tahapan yaitu reduksi data, penyajian data, dan penarikan kesimpulan. Hasil penelitian ini adalah: langkah model PBL yaitu: orientasi masalah, pengorganisasian belajar, pembimbingan, penyajian hasil, analisis dan evaluasi, penerapan model PBL dapat meningkatkan hasil belajar tentang bangun ruang. Kendala penggunaan model PBL: belum semua siswa mengikuti pembelajaran, siswa kesulitan ketika berkelompok, siswa belum mencatat simpulan, siswa belum percaya diri, siswa yang pasif. Solusinya: mengarahkan untuk bergabung dengan teman lain, membagi kelompok sebelum pelaksanaan pembelajaran, meminta siswa mencatat simpulan, memberi motivasi, memberi arahan agar siswa aktif. Simpulan penelitian ini menunjukkan bahwa penerapan model PBL dapat meningkatkan pembelajaran matematika tentang bangun ruang pada siswa kelas $V$ SDN 1 Jatisari tahun ajaran 2020/2021.
\end{abstract}

Kata kunci: Problem Based Learning, Bangun Ruang 


\section{PENDAHULUAN}

Pendidikan adalah salah satu kunci dalam meningkatkan mutu sumber daya manusia, sebab dengan pendidikan dapat menambah pengetahuan, meningkatkan ketrampilan, dan dapat menanamkan nilai-nilai karakter bangsa dengan baik. Pembentukan karakter bangsa yang baik diwujudkan dengan proses pembelajaran yang berdasarkan pada tujuan pendidikan nasional.

Berdasarkan hasil observasi di SDN 1 Jatisari, proses pembelajaran matematika masih jauh dari yang diharapan. Pertama, siswa hanya mendengarkan penjelasan guru, kemudian mencatat materi, dan mengerjakan soal-soal latihan. Kedua, siswa kesulitan ketika diminta mengerjakan soal dari pengembangan materi. Seperti pada materi bangun ruang, siswa tidak mampu menjelaskan pengertian bangun ruang serta masih kesulitan dalam mengerjakan soal yang berkaitan dengan pemecahan masalah bilangan bangun ruang. Kesulitan tersebut menunjukkan bahwa pemahaman konsep bangun ruang, pengerjaan operasi hitung bangun ruang, serta pemecahan masalah yang berkaitan dengan bangun ruang masih kurang. Ketiga, guru masih mendidik dengan metode teacher centered. Guru hanya menggunakan papan tulis dan buku sebagai media pembelajaran, sehingga pemahaman konsep tentang bangun ruang serta pengembangan materi yang berkaitan dengan bangun ruang kurang tertanam secara maksimal. Hal tersebut menunjukkan bahwa model pembelajaran yang digunakan kurang inovatif dalam proses pembelajaran di SDN 1 Jatisari.

Berdasarkan fakta-fakta yang telah di amati di lapangan, didapatkan bahwa pembelajaran yang dilaksanakan di SDN 1 Jatisari belum menggunakan model pembelajaran yang inovatif untuk menunjang proses pembelajaran. Hal tersebut mengakibatkan rendahnya hasil belajar siswa pada mata pelajaran matematika. Dari data yang diperoleh oleh peneliti, didapatkan hasil nilai ulangan tengah semester siswa yang masih rendah. Belum banyak siswa yang memenuhi Krtiteria Ketuntasan Mininal (KKM) yang telah ditetapkan oleh sekolah. KKM yang ditentukan oleh sekolah adalah 68. Dari 12 siswa, hanya ada 2 siswa yang memenuhi batas tuntas. Selain itu, rata-rata nilai ulangan tengah semester siswa baru mencapai 59,6 sedangkan KKM yang dibuat oleh sekolah adalah 68. Dibandingkan nilai ulangan tengah semester yang lain, nilai rata-rata matematika termasuk ketegori paling rendah. Nilai rata-rata IPA= 59,75 , nilai rata-rata Bahasa Indonesia $=70,1$, nilai rata-rata $P K n=60,45$, nilai rata-rata IPS $=59,8$, nilai rata-rata Bahasa Jawa $=59,6$. Oleh karena itu, perlu adanya perbaikan dalam proses pembelajaran untuk meningkatkan kemampuan matematika siswa, serta diperlukan media yang menarik yang dapat menunjang proses pembelajaran sehingga materi yang disampaikan dapat diterima dengan baik oleh siswa, sehingga hasil belajar siswa dapat meningkat dan target sekolah dapat tercapai.

Huda (2014: 6) mengemukakan bahwa pembelajaran merupakan suatu fenomena yang kompleks yang dipengaruhi oleh banyak faktor. Pembelajaran juga merupakan rekonstruksi dari pengalaman masa lalu yang berpengaruh terhadap tingkah laku dan kapasitas seseorang. Matematika merupakan bahan kajian yang memiliki objek abstrak serta dibangun melalui proses penalaran deduktif, yaitu kebenaran suatu konsep diperoleh sebagai akibat logis dari kebenaran yang telah ada sebelumnya dan diterima, sehingga kebenaran antar konsep dalam matematika bersifat sangat kuat dan jelas" (Wahyudi, 2015: 68).

Peningkatan pembelajaran matematika tentang bangun ruang pada siswa kelas $V$ SD adalah proses penyampaian ilmu matematika tentang bangun ruang yang meliputi volume kubus dan baok pada siswa kelas V SD yang berada pada tahap operasional konkret dengan model dan media yang 
dapat menunjang proses pembelajaran, sehingga proses dan hasil belajar siswa menjadi lebih maksimal.

Menurut Dutch (dalam Amir, 2009: 21) Problem Based Learning (PBL) merupakan metode instruksional yang menantang siswa agar "belajar untuk belajar" bekerja sama dalam kelompok untuk mencari solusi bagi masalah yang nyata.

Model model Problem Based Learning (PBL) merupakan suatu model pembelajaran berdasarkan masalah yang disajikan secara sistematis yang berkaitan dengan kehidupan nyata, kemudian siswa diarahkan untuk menyelesaikan masalah tersebut dari berbagai perspektif, sehingga siswa dapat menyusun pengetahuan mereka sendiri, mengembangkan inkuiri dan ketrampilan berpikir tingkat lebih tinggi, mengembangkan kemandirian dan percaya diri, sehingga siswa sungguh-sungguh mendapatkan pemahaman mengenai apa yang sudah dipelajari.

Rumusan masalah dari penelitian tindakan kelas secara kolaboratif ini

yaitu: Apakah penggunaan model Problem Based Learning dapat meningkatkan pembelajaran matematika tentang bangun ruang pada siswa kelas V SDN 1 Jatisari Tahun Ajaran 2020/2021?.

Berdasarkan rumusan masalah, maka tujuan penelitian ini yaitu: Untuk meningkatkan pembelajaran matematika tentang bangun ruang dengan menggunakan model Problem Based Learning pada siswa kelas V SDN 1 Jatisari Tahun Ajaran 2020/2021.

\section{METODE}

Penelitian ini merupakan PTK kolaboratif. Penelitian ini direncanakan dan dilaksanakan di SDN 1 Jatisari. Subjek penelitian ini siswa kelas V SDN 1 Jatisari tahun ajaran 2020/2021 yang berjumlah 12 siswa.

Teknik pengumpulan data dalam penelitian ini dilakukan menggunakan instrumen berupa lembar observasi terhadap guru dan siswa, pedoman wawancara, tes. Analisis data dalam penelitian ini berupa data kuantitatif dan data kualitatif. Analisis data kualitatif menurut Miles dan Huberman (dalam Sugiyono, 2015: 338-345) meliputi reduksi data, penyajian data, dan penarikan kesimpulan. Validitas data dalam penelitian ini menggunakan triangulasi sumber data dan teknik. Triangulasi sumber data dengan melibatkan guru, siswa, dan dokumen. Triangulasi teknik yaitu observasi, wawancara, dan tes.

Penelitian ini dilaksanakan dalam tiga siklus. Prosedur penelitian tindakan kelas dalam penelitian ini yaitu perencanaan, pelaksanaan, pengamatan, dan refleksi (Arikunto, 2013: 137). Pada perencanaan penggunaan model $P B L$, peneliti menyusun RPP dan perangkat lainnya, melakukan koordinasi dengan guru kelas dan menghubungi observer yang akan bertugas. Pada pelaksanaan guru melaksanakan pembelajaran sesuai perencanaan yang telah dibuat. Pada pengamatan, observer mengamati langkah-langkah penggunaan model $P B L$ terhadap guru dan siswa. Pada tahap refleksi dilakukan oleh peneliti, guru kelas, dan observer untuk mendiskusikan kendala yang dihadapi selama pelaksanaan dan mencari solusi agar kendala tersebut dapat diatasi.

\section{HASIL DAN PEMBAHASAN}

Penelitian dilaksanakan dalam tiga siklus. Pelaksanaan pembelajaran dengan menggunakan model Problem Based Learning telah dilaksanakan sesuai dengan skenario pembelajaran yang telah dibuat. Langkah model Problem Based Learning , yaitu (1) orientasi masalah, (2) pengorganisasian belajar, (3) pembimbingan siswa, (4) penyajian hasil kerja, (5) analisis dan evaluasi proses pemecahan masalah.

Pelaksanaan pembelajaran menggunakan model Problem Based Learning yang dilakukan meningkatkan pembelajaran matematika. Peningkatan pembelajaran matematika dapat dilihat dari persentase hasil belajar siswa pada tabel 1 di bawah ini: 
Tabel 1. Perbandingan Persentase Hasil Belajar Siswa

\begin{tabular}{ccc}
\hline \multirow{2}{*}{ Tindakan } & \multicolumn{2}{c}{ Hasil Belajar Siswa } \\
\cline { 2 - 3 } & Nilai Rata-rata & $\begin{array}{l}\text { Persentase } \\
\text { Ketuntasan }\end{array}$ \\
\hline I & 60 & $50 \%$ \\
\hline II & 77 & $75 \%$ \\
\hline III & 83 & $83 \%$ \\
\hline
\end{tabular}

Tabel 1 disimpulkan bahwa nilai hasil belajar siswa mengalami peningkatan. Hal itu terbukti dari nilai rata-rata pada siklus I 60 dengan persentase ketuntasan $50 \%$. Pada siklus II nilai rata-rata meningkat menjadi 77 dengan persentase $75 \%$. Pada siklus III nilai rata-rata menjadi 83 dengan persentase ketuntasan $83 \%$. Data hasil belajar siswa menunjukkan bahwa terjadi peningkatan persentase ketuntasan dan nilai rata-rata hasil tes tertulis.

Penelitian ini menemui beberapa kendala yang ditemui pada ketiga siklus yaitu: (1) belum semua siswa mengikuti pembelajaran melalui googlemeet, (2) siswa kesulitan ketika akan berkelompok, (3) siswa belum mencatat simpulan, (4) siswa belum percaya diri, (5) masih ada siswa yang pasif. . Solusi dari kendala-kendala tersebut, yaitu: (1) mengarahkan siswa yang tidak bisa bergabung dengan googlemeet untuk bergabung dengan teman lain yang bisa masuk googlemeet, (2) guru membagi kelompok sebelum pelaksanaan pembelajaran, sehingga ketika pembelajaran online siswa sudah berkelompok, (3) guru meminta siswa agar mencatat simpulan, (4) guru memberi motivasi agar siswa percaya diri, (5) guru memberi arahan agar siswa lebih aktif dalam pembelajaran.

\section{SIMPULAN}

Berdasarkan hasil penelitian dapat disimpulkan bahwa penggunaan model Problem Based Learning dapat meningkatkan pembelajaran matematika pada siswa kelas V SDN 1 Jatisari tahun ajaran 2020/2021. Peningkatan rata-rata nilai dan persentase ketuntasan hasil belajar siswa pada siklus I 60 dengan persentase ketuntasan $50 \%$. Pada siklus II nilai rata-rata meningkat menjadi 77 dengan persentase $75 \%$. Pada siklus III nilai rata-rata menjadi 83 dengan persentase ketuntasan $83 \%$.

Berdasarkan simpulan yang telah diuraikan perlu mengajukan saran-saran sebagai berikut: (1) Bagi guru, hendaknya dapat memilih model pembelajaran yang tepat untuk digunakan dalam pembelajaran matematika pada siswa kelas $\mathrm{V}$, salah satunya yaitu model Problem Based Learning . (2) Bagi sekolah, hendaknya mendukung dan menfasilitasi guru dalam melaksanakan pembelajaran yang inovatif, seperti menerapkan model Problem Based Learning (PBL). (3) Bagi siswa, hendaknya lebih aktif saat diskusi dan harus memiliki motivasi belajar yang tinggi dalam mengikuti pelajaran. (4) Bagi peneliti lain, dapat dijadikan sebagai referensi tentang pelaksanaan pembelajaran matematika dengan menggunakan model Problem Based Learning $(P B L)$.

\section{DAFTAR PUSTAKA}

Amir, T. (2009). Inovasi Pendidikan Melalui Problem Based Learning. Jakarta: Prenadamedia Group.

Arikunto. (2013). Prosedur Penelitian. Jakarta: Rineka Cipta. 
Volume 9 Nomor 1 Tahun 2021

Huda, M. (2014). Model-Model Pengajaran dan Pembelajaran. Yogyakarta: Pustaka Pelajar.

Sugiyono. (2015). Metode Penelitian Pendidikan. Bandung Alfabeta.

Wahyudi. (2015). Panduan Pembelajaran Matematika Sekolah Dasar (Untuk Guru dan Calon Guru SD). Surakarta: UNS Press 